\title{
Using Public-Private Partnership Tools to Reduce the Negative Environmental Impact of Meat Processing Plants
}

\author{
Igor Vorotnikov*, Konstantin Kolotyrin, and Konstantin Petrov \\ Saratov State Agrarian University named after N.I. Vavilov, Saratov, 410012, Russia, 1 Teatralnaya \\ pl.
}

\begin{abstract}
The issues of reducing the negative environmental impact of meat processing enterprises on the environment are considered. Various types of pollution are analyzed, and the most dangerous sources of pollution are identified. On the basis of the studied references, it is concluded that the solution of the problems of environmental pollution by meat processing enterprises is possible only if economic conditions are created that make environmental projects in the studied sphere of production profitable from an economic point of view. Introduction of modern technologies for processing of raw meat requires significant costs and motivation of all participants associated with production of meat products. In order to solve the problems listed above, it is offered to use tools of public-private partnership in the meat industry in implementation of environmental projects. Particular emphasis is placed on encouraging private investors from the state to reduce the environmental burden on the environment on the basis of various preferential programs and subsidies. The offered instruments of public-private partnership made it possible to achieve an optimal combination between the environmental and economic interests of all participants in the environmental protection process. It is offered to use various forms, such as concession, delegation of management, concession, and etc. as instruments of public-private partnership. It is noted that use of public-private partnerships in projects for environmental protection in the meat processing industry will minimize environmental risks, as well as reduce risks for investors. Use of publicprivate partnerships will also allow attracting additional sources of financing, ensuring information accessibility of production technologies and motivating meat processors to introduce resource-saving production technologies, which will ultimately affect environmental well-being.
\end{abstract}

\section{Introduction}

The food and processing industry is currently the most dynamically developing field of activity, which includes more than 30 types of various industries.

\footnotetext{
*Corresponding author: nir@sgau.ru
} 
The most significant and resource-intensive industry is meat processing, whose products are in demand on the Russian and foreign markets. Wherein, the products of this industry, for the most part, are sold on the domestic market, which is due to various factors, among which the environmental characteristics of the products, as well as use of environmentally friendly technologies in the production process, are of particular importance. Rather significant moral and physical deterioration of fixed assets, which reaches $60 \%$, further exacerbates the environmental problems of the meat processing industry [1-3].

At the moment, the meat industry is represented by the following types of enterprises:

- meat factories and meat and poultry factories;

- poultry factories;

- meat processing plants.

The share of meat processing plants accounts for more than $80 \%$ of enterprises that process meat and slaughter livestock. Due to government support, pork and poultry are the main domestic raw materials for processing enterprises, while beef products are mostly produced from imported raw materials [4].

It is an obvious fact that these enterprises cause significant damage to the environment, since their technological processes are associated with a large number of by-products. figure.

The main directions of pollution from meat processing enterprises are shown in the

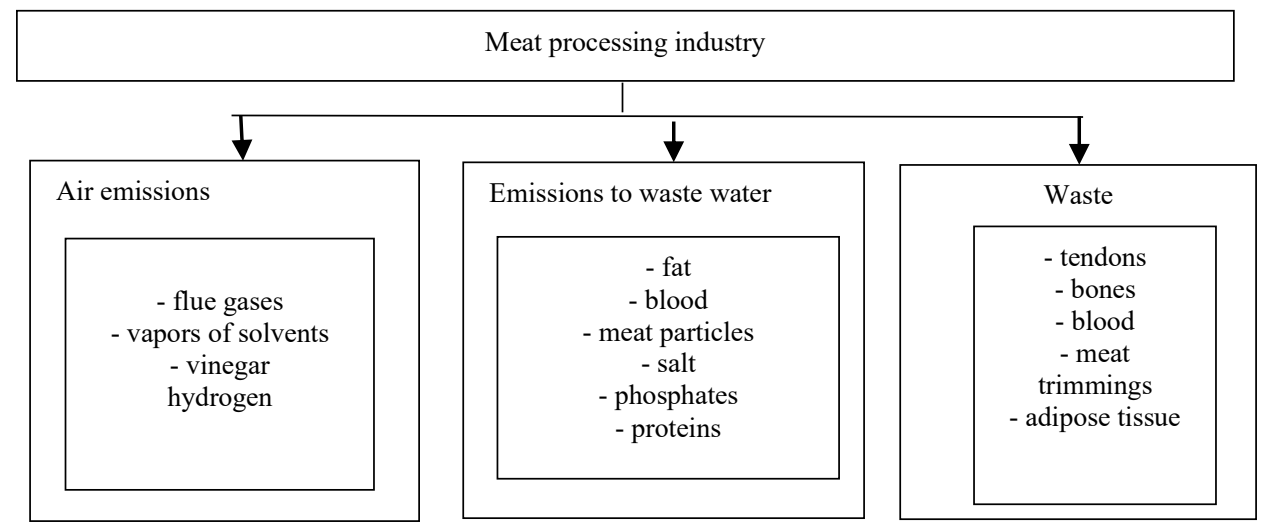

Fig 1. The main types of contamination from meat processing plants.

Many environmental problems from the activities of meat processing plants are associated with air emissions. Namely, most of these enterprises emit various impurities into the air in the form of gases and dust. Technological components and various types of alkalis also enter the atmosphere [5-7]. It shall be noted that the problem of an unpleasant odor present in the air, which appears as a result of the activities of meat processing enterprises, is very urgent, which indicates poor filtration of air emissions.

Significant emissions from the activities of meat processing enterprises also occur in water bodies.

A large volume of water consumption leads to an increased discharge of wastewater, which is polluted at all stages of the technological cycle. Industrial wastewater contains various components, including edible fats, by-product components, and etc. The share of industrial wastewater accounts for up to $70 \%$ of the total volume of discharged water [8$11]$. 
It is noted that wastewater from meat processing plants can be hot and contain organic matter and nitrogen. The meat industry has the potential to generate large quantities of solid waste and biochemical oxygenated wastewater. [12].

It shall be noted that with insufficient treatment and control of wastewater, there may be a risk of infection with pathogenic microorganisms such as E. coli, anthrax, etc., which ultimately can lead to a violation of the sanitary and epidemiological situation.

Another urgent problem associated with environmental pollution by meat processing enterprises is formation of a large amount of various wastes.

Among the wastes of meat processing enterprises, one can single out meat trimmings, skin, tendons, bones, and etc. These waste components, for the most part, are recyclable using modern equipment. The same waste that, for one reason or another, has not been recycled, must be disposed of in a safe way at specialized enterprises. However, as practice shows, a significant proportion of waste is disposed of at unauthorized landfills, which leads to negative environmental consequences.

In scientific papers, the authors [13] come to the conclusion that the growing demand for meat products requires manufacturers to reduce economic costs by minimizing environmental costs, and the integration of various stages of meat production and modernization of equipment will create economic incentives to prevent various types of pollution.

It is noted [14-16] that for the effective solution of environmental problems at food industry enterprises, it is necessary to create the introduction of environmental management systems at enterprises of this type. In this case, the environmental management system will be the driving force for creating environmental and economic incentives for processors in the meat industry. A study within the framework of creation of an environmental management system at meat processing enterprises will make it possible to analyze all technological chains where waste is generated, as well as to monitor the post-sale circulation of manufactured products.

\section{Methods}

Obviously, it will be very difficult to solve the environmental problems of meat processing enterprises without state support, since private traders, in the majority, are aimed at making a profit at any cost, which leads to negative environmental consequences. Wherein, it is necessary to determine the optimal degree of government intervention in the activities of meat processing enterprises.

Namely, the process of transferring Russian meat industry enterprises to European environmental standards can be cited as an example of insufficiently effective government intervention in the activities of meat processing enterprises. In terms of environmental protection, the goal is clear, but the economic impact has not been sufficiently calculated, which has led to problems in the meat processing industries. So, at the moment, enterprises of the meat processing industry are classified as enterprises that cause moderate and significant damage to the environment. As a result, 80-90\% of enterprises were classified as the first category of hazard, which provides for serious restrictions on activities, and as a result, an increase in production costs [17].

In order to develop an effective mechanism for minimizing the negative environmental impact from meat processing enterprises, it is necessary to focus on stimulating nature users to protect the environment, using public-private partnerships and respecting the environmental and economic interests of all participants [18]. 


\section{Results}

The figure shows a diagram with directions for reducing environmental pollution by meat processing enterprises.

Pollution, as noted above, is represented by wastewater discharges, air emissions and waste. In this regard, state participation is necessary, both in stimulating areas and in the field of imposing sanctions.

In the case that a meat-processing enterprise introduces cleaning equipment in itself, it is possible to minimize and process the resulting waste, it is possible to introduce incentive directions within the framework of a public-private partnership.



Fig 2. Minimization of environmental damage from the activities of meat processing enterprises.

Instruments such as tax incentives, concessional lending, leasing, financial and organizational assistance in the implementation of the best available technologies can act as incentives.

The effectiveness of use of incentive directions will be expressed both in the achievement of environmental safety indicators and in economic efficiency.

With third-party processing of waste from meat processing enterprises, the main task is to create incentives for enterprises to formally conclude contracts for waste processing, since enterprises may resort to unauthorized disposal of waste in order to save money. In this regard, the state needs strict control over both the generation of waste and the process of their transportation and processing at specialized enterprises. A special place shall be given to the regulation of tariffs, in order to comply with the interests of both the enterprises that generate waste and the processors of the waste itself.

In certain cases, a situation may arise when it is necessary to dispose of wastes from meat processing enterprises, for example, when it is not possible to process and cremate them. In this case, it is necessary to do this at specialized landfills or biothermal pits. 
In this case, state participation shall consist in creating various barriers to unauthorized burial through various regulatory documents. Particular attention shall be paid to the controlling functions of state authorities, since burial objects pose a particular danger.

In order to reduce environmental risks in implementation of environmental projects at meat processing enterprises, within the framework of a public-private partnership, it is possible to introduce environmental insurance, and the insurance premium can be partially or fully compensated from the state budget.

Considering the possibility of using public-private partnerships at meat processing enterprises in order to liquefy the negative environmental impact, the following advantages can be distinguished both for the state and for the meat processors themselves (table).

It is obvious that many environmental projects within the framework of public-private partnerships will benefit both the public sector and meat processing enterprises.

Namely, use of modern equipment, which will be purchased on preferential terms through government support, will significantly reduce emissions and prevent their direct formation.

Table 1. Benefits of public-private partnerships.

\begin{tabular}{|l|l|}
\hline $\begin{array}{c}\text { Environmental and economic benefits for the } \\
\text { public sector }\end{array}$ & $\begin{array}{l}\text { Environmental and economic benefits for meat } \\
\text { processing plants }\end{array}$ \\
\hline $\begin{array}{l}\text { Improving the environment through preventive } \\
\text { measures }\end{array}$ & $\begin{array}{l}\text { Reducing investment risks in the implementation } \\
\text { of environmental projects }\end{array}$ \\
\hline Reducing state budget expenditures & $\begin{array}{l}\text { The ability to purchase modern equipment on } \\
\text { favorable terms }\end{array}$ \\
\hline $\begin{array}{l}\text { Increasing the environmental and economic } \\
\text { efficiency of ongoing projects }\end{array}$ & $\begin{array}{l}\text { Use of concessional lending, insurance and } \\
\text { leasing in the implementation of environmental } \\
\text { programs }\end{array}$ \\
\hline $\begin{array}{l}\text { Creation of incentives for users of natural } \\
\text { resources through implementation of projects } \\
\text { and programs of environmental protection }\end{array}$ & $\begin{array}{l}\text { Opportunity to enter foreign markets with your } \\
\text { products due to the transition to modern } \\
\text { environmentally friendly production standards }\end{array}$ \\
\hline $\begin{array}{l}\text { Increase in investment and innovation activity of } \\
\text { enterprises }\end{array}$ & $\begin{array}{l}\text { Impact on changing legislation considering the } \\
\text { needs of meat processing enterprises }\end{array}$ \\
\hline $\begin{array}{l}\text { Ensuring "transparency" of financing processes } \\
\text { for projects to reduce the environmental burden } \\
\text { of meat processing enterprises }\end{array}$ & $\begin{array}{l}\text { Reducing the cost of various penalties and } \\
\text { recovery measures }\end{array}$ \\
\hline
\end{tabular}

Attraction of government funding will create real incentives for investment in projects to introduce the best available technologies at meat processing plants.

Another undoubted advantage of using public-private partnerships for the meat industry will be the ability to enter foreign markets with products, since most European countries allow products to their markets that are produced only on the basis of environmentally friendly technologies.

It shall be noted that within the framework of public-private partnerships, when introducing environmental projects at meat processing enterprises, government bodies can:

- to provide the necessary equipment for temporary use;

- participate in co-financing of projects related to environmental protection;

- provide guarantees for investors;

- compensate for the costs at preferential rates for loans, leasing, and etc.

The main forms that can be used within the framework of public-private partnerships in implementation of environmental projects at meat processing enterprises will be delegation of management, lease, and concession.

Namely, such a form of public-private partnership as leasing provides for provision of equipment on preferential terms to users of natural resources, in this case, meat processing 
enterprises. Rent can be in the form of leasing, while the preferential part of the interest rate can be compensated for by government resources.

Delegation of management can be associated with the transfer of certain functions of state management to private companies, for example, in the implementation of the process of neutralizing waste from meat processing enterprises.

Conclusion of a concession agreement can be extended to infrastructure facilities, for example, territories adjacent to meat processing enterprises, waste storage facilities, etc.

The effectiveness of using these forms of public-private partnership in implementation of environmental projects at meat processing enterprises will be determined by the following aspects:

- the high level of adaptation of the project to changing conditions, which will significantly increase the environmental and economic efficiency of the meat processing plants;

- the ability to redistribute risks between all participants in environmental projects in the field of meat processing, according to the principle of their best management;

- to create incentives for users of natural resources to respect the environment by providing certain benefits and preferences;

- to increase the effectiveness of projects to eliminate past environmental damage from the activities of meat processing enterprises;

- to ensure the investment attractiveness of projects to reduce negative environmental consequences from the activities of meat processing enterprises. By providing additional guarantees and reducing risks for investors.

Implementation of projects for protection of the environment at meat processing enterprises is associated with certain stages, which are shown in Figure 3.

At the first stage of implementation of environmental projects at meat processing enterprises, it is necessary to consider technological aspects considering the environmental and economic efficiency. Existing best available technology guides provide reasonably efficient technologies that can be implemented in meat processing plants. Introduction of these technologies on the basis of public-private partnerships will ensure not only environmental efficiency, but also increase economic performance.

It shall be noted that technological directions in implementation of environmental projects at meat processing enterprises shall be based on the analysis of various technical risks and regulatory conditions. In the future, it is necessary to compare the planned performance indicators with the priority areas of the project being implemented.

To assess the environmental and economic efficiency of public-private partnership in this project, it is necessary to determine the optimal degree of participation of state authorities, for example, use of concessional lending and leasing, subsidies, participation in investment, government orders, and etc. 
Project for introduction of environmentally friendly technologies at meat processing enterprises

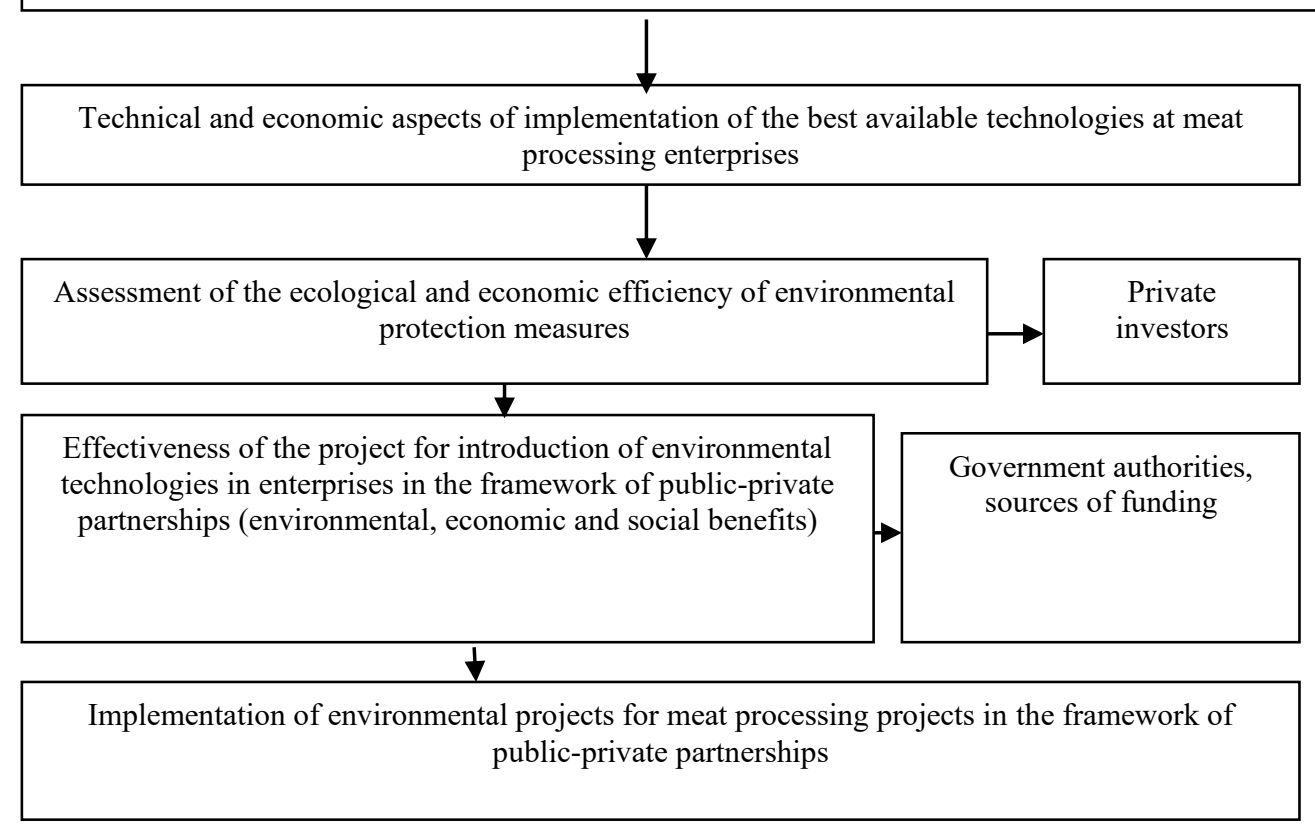

Fig 3. Stages of implementation of environmental projects at meat processing enterprises within the framework of public-private partnership

Evaluation of the environmental and economic efficiency of the project shall coincide with the interests of meat processing enterprises. Of course, for these enterprises operating on a private basis, the main criterion of efficiency will be the ability to maximize profits. In this regard, it is necessary to provide conditions for implementation of the project on the basis of environmental and economic efficiency for private enterprises and stimulate them to respect the environment. Environmental interests for the meat processing industry will be expressed in the image component of the enterprise, for example, to enter the European market.

The effectiveness of public participation shall be measured by environmental, economic and social indicators. Most of the economic interests may coincide with the interests of private enterprises. Environmental benefits will be measured in reducing the negative environmental impact of meat processing enterprises on the environment. Social aspects are related to the health of the population, improvement of the standard and quality of life.

If all of the above requirements are met, a project that ensures the environmental safety of meat processing enterprises can be implemented.

\section{Conclusion}

Therefore, on the basis of the above, we can conclude that use of public-private partnership tools in implementation of projects to reduce the negative environmental impact of meat processing enterprises on the environment will provide the following benefits:

- to speed up the process of introducing modern high-tech equipment at meat industry enterprises, ensuring the environmental safety of technological processes; 
- to reduce the expenditures of the state budget at the expense of private investment resources;

- to attract investors to implementation of environmental protection measures in the meat industry by providing additional guarantees and ensuring the transparency of transactions;

- to create additional incentives to respect the environment through a system of motivation from the state;

- to minimize risks due to their optimal redistribution between participants in the meat production process;

- to increase the profitability of production processes through use of modern resourcesaving equipment.

Summarizing the above, we can conclude that use of public-private partnership instruments in order to reduce the negative environmental burden from meat processing enterprises will create real incentives for environmental protection among producers-users of natural resources by minimizing risks, providing additional financing and guarantees to investors from the side of state, as well as increase the competitiveness of products.

\section{References}

1. Z. Petrovica, V. Djordjevica, D. Milicevica, I. Nastasijevica, N. Parunovica, International 58th Meat Industry Conference «Meat Safety and Quality: «Where it goes?» (2017)

2. R. Yorka, M.H. Gossard, Ecol Eco (2004)

3. B. Pagan, P. Prasad, J. Clean Prod (2007)

4. S. Schwarzer, R. Witta, Z. Zommer, Environ Dev (2013)

5. L. Melvin, Myers Livestock production: its scale and potential impact on human health (2017)

6. L. P. Lazareva, O. N. Kostryakova, IOP Conf. Series: Materials Science and Engineering (2017)

7. M.K. Kamilov, P.D. Kamilova, Z.M. Kamilova, Regional'nye problemy preobrazovaniya ekonomiki, 1 (2017)

8. F. Allievi, M. Vinnari, J. Luukkanen, J. Clean Prod (2015)

9. I. Djekica, International 58th Meat Industry Conference «Meat Safety and Quality: Where it goes?» (2017)

10. G. Kaletnik, S. Lutkovska, European Journal of Sustainable Development, 10, 1 (2021)

11. C. Basset-Mens, HMG van der Werf, EcosystEnviron (2005)

12. I.M. Potravnyj, K.P. Kolotyrin, I.B. Gengut, Ekonomicheskaya nauka sovremennoj Rossii, 77, 2 (2017)

13. L.G. Mel'nik, L. Hens, Sumy (ITD Universitetskaya kniga, 2007)

14. I.L. Vorotnikov, K.P. Kolotyrin, O.V. Vlasova, Economic Annals -XXI, 9 (2014)

15. L. Nemenushchaya, L. Konovalenko, T. Shchegolikhina, IOP Conf. Series: Earth and Environmental Science, 403 (2019)

16. D.YU. Savon, K.P. Kolotyrin, A.V. Romanov, Ekonomika v promyshlennosti, 12, 3 (2019) 
17. E.G. Gasho, E. Stepanova, Nailuchshie dostupnye tekhnologii. Primenenie v razlichnyh otraslyah promyshlennosti (Moskva, «Pero», 2017)

18. I.L. Vorotnikov, K.P. Kolotyrin, O.V. Vlasova, K.A. Petrov, Optimization of agricultural products storage and marketing on the basis of logistics espacios, 49, 38 (2017)

19. TLT Nguyen, J.E. Hermansen, L. Mogensen, J. Cleaner Prod (2012) 